\title{
PENGEMBANGAN MODUL PEMBELAJARAN KIMIA DASAR TERINTEGRASI SOCIO-SCIENTIFIC ISSUE (SSI) DAN KEISLAMAN
}

\author{
Moh. Ismail Sholeh \\ Universitas Islam Negeri Raden Fatah Palembang \\ E-mail: Moh.ismailsholeh@ radenfatah.ac.id
}

\begin{abstract}
Abstrak: Program Studi Pendidikan Kimia UIN Raden Fatah Palembang merupakan program studi di bawah kementrian agama yang memiliki tujuan yaitu mewujudkan lulusan sarjana pendidikan kimia yang menguasi konsep, teori dan praktek dalam bidang pendidikan kimia secara profesional serta mampu mengintegrasikan nilai-nilai ke Islaman. Untuk mencapai hal tersebut, salah satunya diperlukan bahan ajar yang kimia yang inovatif, mudah dipelajari, memuat materi yang mendalam serta terintegrasi nilai-nilai ke-Islaman. Oleh karena peneliti mengembangkan modul kimia dasar ang terintegrrasi niilai-nilai ke Islaman serta socio-scientific issue. Penelitian ini bertujuan untuk: (1) mengetahui validitas modul kimia dasar terintegrasi socio-scientific issue (SSI) dan ke Islaman; (2) mengetahui efektivitas modul kimia dasar terintegrasi socio-scientific issue (SSI) dan ke Islaman; (3) mengetahui respon Mahasiswa terhadap modul kimia dasar terintegrasi socio-scientific issue (SSI) dan ke Islaman. Penelitian ini menggunakan metode penelitian Research and Development (R\&D). Model yang digunakan adalah pengembangan model 4-D. Hasil pengembangan media divalidasi oleh ahli media dan ahli materi. Hasil penelitian menunjukkan bahwa: (1) Modul kimia dasar terintegrasi socio-scientific issue (ssi) dan keIslaman valid dan layak digunakan. Berdasarkan penilaian ahli materi, dan media didapatkan presentase kelayakan isi 96\% (sangat layak), kelayakan penyajian 96\% (sangat layak), penilaian ssi dan keislaman 98\% (sangat layak), kelayakan kegrafikan 95\% (sangat layak) dan penilaian kebahasaan 97\% (sangat layak). Selain itu, kelayakan juga diperoleh dari tanggapan mahasiswa uji skala kecil dengan presentase $94 \%$ (sangat baik) dan tanggapan dosen uji skala kecil sebesar $80 \%$ (baik). (3) Modul kimia dasar terintegrasi socio-scientific issue (ssi) dan keIslaman efektif digunakan dalam pembelajaran. Dilihat dari hasil perhitungan $\mathrm{N}$-gain dengan hasil 0.45 (sedang). Untuk Uji $\mathrm{t}$ dihasilkan dengan hasil perhitungan harga $t_{\text {hitung }}>t_{\text {tabel }}(16,08>1,68)$ sehingga terdapat perbedaan secara signifikan pada hasil belajar mahasiswa. (4) Persentase respons mahasiswa setelah penggunaan Modul kimia dasar terintegrasi socio-scientific issue (ssi) dan keIslaman secara secara klasikal $85 \%$ (sangat baik).
\end{abstract}

Kata kunci: Modul, Sosico-scientific issue (SSI), keIslaman

\section{PENDAHULUAN}

Program Studi Pendidikan Kimia UIN Raden Fatah Palembang merupakan program studi di bawah kementrian agama memiliki tujuan yaitu mewujudkan lulusan sarjana pendidikan kimia yang menguasi konsep, teori dan praktek dalam bidang pendidikan kimia secara profesional serta mampu mengintegrasikan nilainilai ke Islaman. Untuk mencapai hal tersebut, salah satunya diperlukan bahan ajar yang kimia yang inovatif, mudah dipelajari, memuat materi yang mendalam serta terintegrasi nilai-nilai ke-Islaman. Berdasarkan data dari perpustakaan pusat UIN Raden Fatah, judul buku yang memuat konten kimia masih minim yaitu kurang dari 100 judul buku. Konten dalam buku teks yang digunakan dalam pembelajaran kimia tidak banyak terhubung dengan pengetahuan kehidupan sosial 
Mahasiswa dan tidak terintegrasi dengan nilai-nilai ke-Islaman. Beberapa buku teks mengacu kepada kurikulum yang meminta Mahasiswa mengingat konsep dan tidak meminta Mahasiswa untuk menemukan arti dan relevansi kepada kehidupannya baik secara pribadi, masyarakat maupun negara.

Kimia dasar merupakan salah satu topik mata kuliah wajib dalam prodi pendidikan kimia. Mata kuliah ini mempelajari hal-hal dasar dalam kimia yang menjadi prasyarat untuk mata kuliah lanjut, seperti kimia fisika, kimia anorganik, kimia organik dan kimia koordinasi. Dalam mata kuliah kimia dasar, ada beberapa topik yang berkaitan dengan issue sosial berbasis kimia, seperti asam basa, kinetika, kesetimbangan kimia dan elektrokimia. Issue sosial ini dikenal dengan istilah "socioscientific issue” (SSI) (Fowler, Zeidler, \& Sadler, 2009). Isu sosial saintifik (socioscientific issue) tidak banyak dimasukan dalam buku teks, padahal isu ini sangat penting karena: (a) membuat pelajaran sains lebih relevan bagi kehidupan, (b) mengarahkan hasil belajar seperti apresiasi terhadap sains, (c) meningkatkan argumentasi dalam berdialog, (d) meningkatkan kemampuan dalam mengevaluasi data dan informasi ilmiah, dan (e) merupakan komponen penting dalam literasi sains (Sadler \& Zeidler, 2004: 6). Studi empiris menunjukkan bahwa socioscientific isuue (SSI) dapat berfungsi sebagai mekanisme epistemologis yang mempromosikan karakter dan nilai-nilai serta meningkatkan perspektif global Mahasiswa (Lee, et al., 2013).

Aspek lain yang tidak kalah pentingnya adalah integrasi nilai ke Islaman dalam buku teks dengan cara menghubungkan konteks materi kimia dengan pandangan menurut Islam. Hal ini bisa dilakukan karena ajaran Islam tidak pernah melakukan dikotomi antar ilmu satu dengan yang lain. Bangunan keilmuan dengan segala ragamnya, baik agama, sosial dan humaniora, maupun ke-alaman tidak dapat berdiri sendiri. Akan tetapi kerjasama, saling tegur sapa, saling membutuhkan, saling koreksi dan saling keterhubungan antar disiplin keilmuan akan lebih dapat membantu kompleksitas persoalan kehidupan dan sekaligus upaya pemecahannya (Abdullah dalam darda, 2015). Berdasarkan uraian di atas, peneliti tertarik untuk mengembangkan modul kimia yang terintegrasi socioscientific issue (SSI) dan ke Islaman pada mata kuliah kimia dasar. 


\section{METODE PENELITIAN \\ Jenis Penelitian}

Metode yang digunakan dalam penelitian ini adalah penelitian dan pengembangan. Model yang digunakan adalah pengembangan model 4-D. Model ini dikembangkan oleh S. Thiagarajan, Dorothy S. emmel, dan Melvyn I. Semmel $(1974: 5)$

\section{Prosedur Pengembangan}

Desaian pengembangan dalam penelitian ini adalah desain 4-D. Model pengembangan 4D terdiri atas 4 tahap utama yaitu: Define (Pendefinisian), Design (Perancangan), Develop (Pengembangan) dan Disseminate (Penyebaran). Pada tahap petama pendefinisian (define) dilakukan beberapa hal diantaranya: analisis kurikulum, analisis karakteristik peserta didik, analisis materi dan merumuskan. Pada tahap kedua perancangan (design) yaitu memilih bentuk penyajian modul yang dikembangkan. Pada Tahap ketiga pengembangan (develop) dilakukan dilakukan kegiatan validasi modul oleh ahli/pakar, revisi modul, uji coba skala kecil, revisi model dan penerapan model dalam kelas besar. Validasi ahli digunakan untuk mengetahui kevalidan instrumen, kevalidan produk dan untuk mendapatkan masukan dan saran perbaikan atas produk dan isntrumen yang terbentuk. Data validasi yang diperoleh dari ahli dianalisis kemudian jika masih terdapat kriteria validasi yang belum terpenuhi maka dilakukan revisi. Pada tahap keempat penyebarluasan (dessiminate) dilakukan sosialisasi modul dalam jumlah terbatas kepada dosen dan mahasiswa.

\section{Subjek Penelitian}

Subjek penelitian ini yaitu mahasiswa Prodi Pendidikan Kimia yang telah mengambil mata kuliah Kimia Dasar Tahun pelajaran 2018/2019

\section{Lokasi Penelitian}

Lokasi penelitian dilaksanakan di Program Studi Pendidikan Kimia UIN Raden Fatah Palembang

\section{Teknik Pengumpulan data}

Teknik pengumpulan data pada penelitian pengembangan ini yaitu: observasi, wawancara, dokumentsi, angket dan kuesioner. 


\section{Teknik Analisis Data}

Teknik analisis data meliputi analisis analisis produk dan uji hipotesis. Analisis produk terdiri dari: analisis kelayakan produk dan analisis tanggapan dosen dna mahasiswa. Analisis kelayakan produk yaitu diambil dari penilaian instrument kelayakan produk modul yang terintegrasi socioscience issue dan ke Islaman oleh tim ahli. . Instrumen penilaian kelayakan media oleh pakar dianalisis dengan rumus:

$$
N P=\frac{R}{S M} \times 100 \%
$$

(Poerwanto, 2013:103)

Keterangan:

$\mathrm{NP} \quad=$ Nilai persen yang diharapkan

$\mathrm{R} \quad=$ skor yang diperoleh

$\mathrm{SM} \quad=$ skor maksimal

Tabel 1. Kriteria Kelayakan Modul

\begin{tabular}{ll}
\hline Presentase & Kriteria \\
\hline $82 \%<$ skor $\leq 100 \%$ & Sangat Layak \\
$63 \%<$ skor $\leq 81 \%$ & Layak \\
$44 \%<$ skor $\leq 62 \%$ & Cukup Layak \\
$25 \%<$ skor $\leq 43 \%$ & Tidak Layak \\
\hline
\end{tabular}

Analisis tanggapan dosen dan Mahasiswa diambil dari penilaian instrument kelayakan produk modul yang terintegrasi socioscience issu dan ke Islaman oleh dosen dan Mahasiswa. Instrumen penilaian kelayakan media oleh pakar dianalisis dengan rumus:

$$
N P=\frac{R}{S M} \times 100 \%
$$

(Poerwanto, 2013:103)

Keterangan:

$\mathrm{NP}=$ Nilai persen yang diharapkan

$\mathrm{R} \quad=$ skor yang diperoleh

$\mathrm{SM}=$ skor maksimal 
Tabel 2. Tanggapan Dosen dan Mahasiswa

\begin{tabular}{ll}
\hline Presentase & Kriteria \\
\hline $82 \%<$ skor $\leq 100 \%$ & Sangat Layak \\
$63 \%<$ skor $\leq 81 \%$ & Layak \\
$44 \%<$ skor $\leq 62 \%$ & Cukup Layak \\
$25 \%<$ skor $\leq 43 \%$ & Tidak Layak \\
\hline
\end{tabular}

Uji hipotesis digunakan untuk menjawab rumusan masalah 2 dengan menggunakan program IBM SPSS for Windows 22, yaitu uji gain dan ukuran effect:

\section{a. Uji t}

Uji t digunakan untuk mengetahui peningkatan hasil belajar siswa dari hasil pretest dan posttest terdapat perbedaan yang signifikan atau tidak. Karena data saling berhubungan digunakan uji t-test dengan sampel berkorelasi pada statistik parametris. Jika $\mathrm{t}$ hitung $>\mathrm{t}$ tabel, maka $\mathrm{H}_{1}$ diterima. Sebaliknya, jika $\mathrm{t}$ hitung < t tabel, maka $\mathrm{H}_{\mathrm{o}}$ diterima. Berikut hipotesisnya:

$\mathrm{H}_{\mathrm{o}}$ : tidak terdapat perbedaan yang signifikan hasil belajar mahasiswa antara sebelum dan sesudah dilakukan proses pembelajaran dengan menggunakan modul kimia dasar yang terintegrasi socio-scientific issue (SSI) dan KeIslaman

$\mathrm{H}_{1}$ : terdapat perbedaan yang signifikan hasil belajar mahasiswa antara sebelum dan sesudah dilakukan proses pembelajaran dengan menggunakan modul kimia dasar yang terintegrasi socio-scientific issue (SSI) dan KeIslaman

Pada penelitian ini, peneliti menggunakan rumus $t$-test. Berikut adalah rumus t-test : 


$$
t=\frac{\overline{x_{1}}-\overline{x_{2}}}{\sqrt{\frac{s_{1}{ }^{2}}{n_{1}}}+\frac{s_{2} 2}{n_{2}}-2 r\left(\frac{s_{1}}{\sqrt{n_{1}}}\right)\left(\frac{s_{2}}{\sqrt{n_{2}}}\right)}
$$

(Sugiyono, 2010: 122)

Keterangan:

$$
\begin{aligned}
& \overline{x_{1}}=\text { rata }- \text { rata sampel } 1 \\
& \overline{x_{2}}=\text { rata }- \text { rata sampel } 2 \\
& s_{1}=\text { simpangan baku sampel } 1 \\
& s_{2}=\text { simpangan baku sampel } 2 \\
& s_{1^{2}}=\text { varians sampel } 1 \\
& s_{2^{2}}=\text { varians sampel } 2 \\
& r \quad=\text { korelasi antara dua sampel }
\end{aligned}
$$

\section{b. Uji Gain}

Normalisasi gain (g) didefinisikan sebagai selisih skor pretest dan postest dibagi jumlah maksimum kenaikan.

$$
G=\frac{\text { postscore } \%-\text { prescore } \%}{100-\text { prescore } \%}
$$

Kriteria nilai (g) disajikan pada Tabel 3

Tabel 3. Kriteria Nilai g

\begin{tabular}{ll}
\hline Nilai $\mathrm{g}$ & Kategori \\
\hline$(\mathrm{g}) \leq 0.30$ & Rendah \\
$0.30 \leq(\mathrm{g}) \leq 0.70$ & Medium \\
$(\mathrm{g}) \geq 0.70$ & Tinggi \\
\hline
\end{tabular}

(Hake dalam Coletta, 2005)

\section{HASIL DAN PEMBAHASAN}

Bab ini memaparkan hasil penelitian dan pembahasan meliputi: 1) Karakteristik modul yang terintegrasi dengan socioscientific issue (SSI) dan Ke Islaman sebagai bahan ajar untuk mata kuliah kimia dasar di Prodi Pendidikan 
Kimia UIN Raden Fatah; 2) Kevalidan modul yang terintegrasi dengan socioscientific issue (SSI) dan Ke Islaman sebagai bahan ajar untuk mata kuliah kimia dasar di Prodi Pendidikan Kimia UIN Raden Fatah; 3) Keefektifan modul yang terintegrasi dengan socioscientific issue (SSI) dan Ke Islaman sebagai bahan ajar untuk mata kuliah kimia dasar di Prodi Pendidikan Kimia UIN Raden Fatah.

\section{Validasi Desain Modul oleh Ahli}

Sebelum modul dapat digunakan untuk menunjang proses pembelajaran, maka harus melalui penilaian dari pakar yakni pakar media dan materi. Modul ini diuji kelayakannya oleh ahli media dan ahli materi dengan mengisi instrumen validasi penilaian dari BSNP (2016) yang telah dikembangkan. Uji kelayakan pada tahap validasi materi terdiri dari empat aspek, yaitu: aspek kelayakan isi, aspek kelayakan penyajian, aspek kelayakan kebahasaan dan aspek penilaian integrasi socioscientific issue dan keIslaman. Hasil rata-rata penilaian validasi desain dapat dilihat pada tabel berikut.

Tabel 4 Penilaian Validator

\begin{tabular}{llllllll}
\hline & & \multicolumn{2}{l}{ Aspek Penilaian } & & & \\
\cline { 3 - 7 } No & Pakar & Kegrafikan & Isi & Penyajian & Kebahasaan & $\begin{array}{l}\text { Integrasi SSI } \\
\text { dan } \\
\text { KeISlaman }\end{array}$ & Persentase (Kriteria) \\
\hline 1 & Media & 53 & - & - & - & - & $95 \%$ (Sangat Layak) \\
\hline 2 & Materi & - & 12 & 11 & 15 & 23 & $95 \%$ (Sangat Layak) \\
\hline
\end{tabular}

Berdasarkan tabel di atas, maka dapat disajikan dalam bentuk diagram batang seperti berikut ini. 


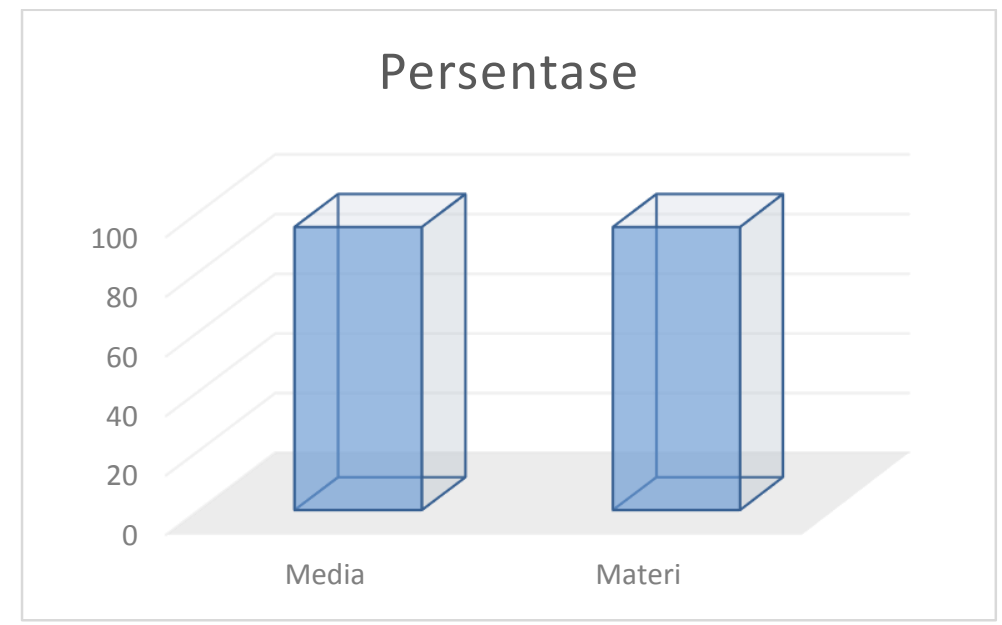

Gambar 1 Diagram Persentase Penilaian Validator

Berdasarkan tabel 4 dan gambar 1 dapat disimpulkan bahwa masingmasing validator memberikan nilai $>63 \%$, hal tersebut berarti produk modul yang dikembangkan memenuhi kriteria layak untuk digunakan. Berikut ini adalah nilai produk modul yang dikembangkan setiap aspeknya

Tabel 5 Persentase Penilaian Produk Bahan Ajar Setiap Aspek

\begin{tabular}{lllll}
\hline No & Aspek Penilaian & $\begin{array}{l}\text { Jumlah } \\
\text { Skor }\end{array}$ & Persentase & Kriteria \\
\hline 1 & Kelayakan Kegrafikan & 53 & $95 \%$ & Sangat Layak \\
2 & Kelayakan Isi & 23 & $96 \%$ & Sangat Layak \\
3 & Penilaian Penyajian & 23 & $96 \%$ & Sangat Layak \\
4 & Kelayakan Kebahasaan & 31 & $97 \%$ & Sangat Layak \\
5 & Kelayakan SSI dan & 47 & $98 \%$ & Sangat Layak \\
& KeIslaman & & & \\
\hline
\end{tabular}

Berdasarkan data dalam tabel 5 data tersebut dapat ditampilkan dalam diagram berikut ini. 


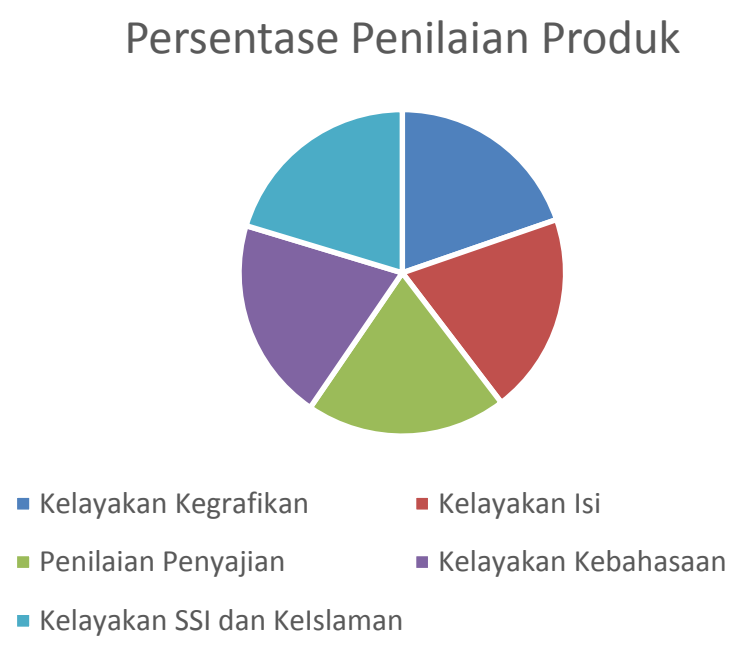

Gambar 2. Persentase Penilaian Produk Bahan Ajar Setiap Aspek

Berdasarkan tabel 5 dan gambar 2 dapat disimpulkan bahwa masingmasing aspek memenuhi kelayakan untuk digunakan pada tahap lanjutan, dengan rincian, aspek kelayakan kegrafikan 95\% (Sangat layak), aspek kelayakan isi 96\% (sangat layak), aspek kelayakan penyajian 96\% (sangat layak), aspek kelayakan kebahasaan 97\% (sangat layak), dan aspek kelayakan SSI dan KeIslaman 98\% (sangat layak).

\section{Revisi Draft II Modul}

Revisi desain merupakan tahap perbaikan desain bahan ajar Modul. Perbaikan dilakukan atas saran atau masukan dari pakar guna memperoleh produk yang layak untuk digunakan dalam proses pembelajaran. ada beberapa saran yang didapatkan setelah validasi desain dilakukan. Beberapa saran tersebut yaitu perbaikan kata-kata yang salah dan penmabahan eksperimen di dalam modul

\section{Uji Coba Skala Kecil}

Modul yang sudah direvisi berdasarkan saran dari pakar kemudian diuji coba dalam skala kecil yaitu menggunakan 9 orang mahasiswa yang diambil dari 3 mahasiswa yang memiliki rerata nilai tertinggi, 3 mahasiswa yang memiliki rerata nilai sedang dan 4 mahasiswa yang memiliki rerata nilai terendah dari 54 mahasiswa. Rekapitulasi respons dosen dan mahasiswa disajikan pada tabel 
berikut ini.

Tabel 6 Rekapitulasi Hasil Respon Dosen Uji Coba Skala Kecil

\begin{tabular}{lllll}
\hline No & Aspek yang ditanyakan & $\begin{array}{l}\text { Presentas } \\
\text { e dosen }\end{array}$ & $\begin{array}{l}\text { Presentase } \\
\text { mahasiswa }\end{array}$ & Kriteria \\
\hline 1 & $\begin{array}{l}\text { Penampilan unsur tata letak pada sampul } \\
\text { muka, belakang dan punggung secara } \\
\text { harmonis memiliki irama dan kesatuan } \\
\text { serta konsisten. }\end{array}$ & $75 \%$ & $100 \%$ & Baik \\
\hline 2 & $\begin{array}{l}\text { Huruf yang digunakan menarik dan } \\
\text { mudah dibaca }\end{array}$ & $100 \%$ & $97 \%$ & $\begin{array}{l}\text { Sangat } \\
\text { Baik }\end{array}$ \\
\hline 3 & $\begin{array}{l}\text { Bentuk, warna, ukuran, proporsi obyek } \\
\text { sesuai realita. }\end{array}$ & $75 \%$ & $95 \%$ & Baik \\
\hline 4 & $\begin{array}{l}\text { Kelengkapan dan kedalaman materi } \\
5\end{array}$ & $75 \%$ & $95 \%$ & Baik \\
\hline 6 & Mendorong rasa ingin tahu & $75 \%$ & $92 \%$ & Baik \\
\hline 7 & $\begin{array}{l}\text { Meakuratan konsep dan definisi } \\
\text { berdasarkan pengetahuan awal yang } \\
\text { dimilikinya. }\end{array}$ & $75 \%$ & $83 \%$ & Baik \\
\hline 8 & Ketepatan struktur kalimat & $86 \%$ & Baik \\
\hline 9 & Keterlibatan peserta didik & $75 \%$ & $100 \%$ & Baik \\
\hline 10 & $\begin{array}{l}\text { Kesesuaian dengan perkembangan } \\
\text { intelektual dan emosional peserta didik. }\end{array}$ & $75 \%$ & $94 \%$ & Baik \\
\hline Presentase secara klasikal & $80 \%$ & $94 \%$ & Baik \\
\hline \multicolumn{1}{c}{ Kiteria } & Baik & Sangat baik & \\
\hline
\end{tabular}

Berdasarkan data pada tabel 6 hasil respons dosen mata kuliah kimia dasar kelas A menunjukkan tanggapan yang baik untuk produk Modul yang diuji cobakan. Hal tersebut ditunjukkan dengan hasil persentase paling rendah hanya $75 \%$ untuk aspek 1, 3, 4, 5, 6, 8, 9 dan 10. Sedangkan persentase paling tinggi yaitu 100\% untuk aspek 2 dan 7. Sedangkan respon dosen secara klasikal diperoleh skor $80 \%$ dengan kriteria baik.

Berdasarkan data pada tabel 6 hasil respons mahasiswa uji coba pemakaian dari 9 mahasiswa kelas A Prodi Pendidikan Kimia menunjukkan tanggapan yang baik bagi produk Modul yang diuji cobakan. Hal tersebut ditunjukkan dengan hasil persentase paling rendah hanya $83 \%$ untuk aspek 6 yaitu Modul ini terdapat beberapa bagian untuk saya menemukan konsep sendiri. Sedangkan persentase paling tinggi yaitu 100\% untuk aspek 1, 8, dan 10 . 
Sedangkan respons mahasiswa secara klasikal diperoleh skor $94 \%$ dengan kriteria sangat baik

\section{Uji Coba Skala Besar}

Uji coba skala besar dilakukan dengan memberikan pembelajaran terhadap 54 mahasiswa dari kelas A Prodi Pendidikan Kimia. Modul digunakan sebagai penunjang proses pembelajaran. Rekapitulasi angket tanggapan dosen dan mahasiswa dapat dilihat pada tabel berikut.

Tabel 7 Rekapitulasi Hasil Respon Dosen Uji Coba Skala Besar

\begin{tabular}{clccc}
\hline No & \multicolumn{1}{c}{ Aspek yang ditanyakan } & $\begin{array}{c}\text { Presentase } \\
\text { dosen }\end{array}$ & $\begin{array}{c}\text { Presentase } \\
\text { mahasiswa }\end{array}$ & Kriteria \\
\hline 1 & $\begin{array}{l}\text { Penampilan unsur tata letak pada sampul } \\
\text { muka, belakang dan punggung secara } \\
\text { harmonis memiliki irama dan kesatuan } \\
\text { serta konsisten }\end{array}$ & $100 \%$ & $89 \%$ & Baik \\
\hline 2 & $\begin{array}{l}\text { Huruf yang digunakan menarik dan } \\
\text { mudah dibaca }\end{array}$ & $100 \%$ & $81 \%$ & $\begin{array}{c}\text { Sangat } \\
\text { baik }\end{array}$ \\
\hline 3 & $\begin{array}{l}\text { Bentuk, warna, ukuran, proporsi obyek } \\
\text { sesuai realita }\end{array}$ & $100 \%$ & $84 \%$ & Baik \\
\hline 4 & Kelengkapan dan kedalaman materi & $75 \%$ & $86 \%$ & Baik \\
\hline 5 & Mendorong rasa ingin tahu & $100 \%$ & $83 \%$ & Baik \\
\hline 6 & Keakuratan konsep dan definisi & $100 \%$ & $83 \%$ & Baik \\
\hline 7 & $\begin{array}{l}\text { Membangun pengetahuan mahasiswa } \\
\text { berdasarkan pengetahuan awal yang } \\
\text { dimilikinya }\end{array}$ & $100 \%$ & $81 \%$ & Sangat \\
baik
\end{tabular}

Berdasarkan data pada tabel 7 hasil respon dosen kelas A Prodi Pendidikan Kimia menunjukkan tanggapan yang sangat baik untuk produk Modul. Hal tersebut ditunjukkan dengan hasil persentase paling rendah hanya $75 \%$ untuk aspek 4 yaitu kelengkapan dan kedalaman materi. Sedangkan persentase paling tinggi yaitu 100\% untuk aspek 1, 2, 3, 5, 6, 7, 8, 9 dan 10. Sedangkan respons 
dosen secara klasikal diperoleh skor 97\% dengan kriteria baik.

Berdasarkan data pada tabel 7 hasil respon mahasiswa uji coba kelas besar 54 mahasiswa kelas A Prodi Pendidikan Kimia. menunjukkan tanggapan yang sangat baik bagi produk Modul yang diuji cobakan. Hal tersebut ditunjukkan dengan hasil persentase paling rendah hanya 81\% untuk aspek 2 dan 7 yaitu Modul ini membuat saya lebih bersemangat belajar dan penyajian materi dalam Modul ini mendorong saya untuk berdiskusi dengan teman yang lain. Sedangkan persentase paling tinggi yaitu $89 \%$ untuk aspek 1 yaitu tampilan Modul ini menarik. Sedangkan respons mahasiswa secara klasikal diperoleh skor $85 \%$ dengan kriteria sangat baik.

\section{Analisis Data}

Analisis data pada tahap ini yaitu analisis data hasil belajar kognitif mahasiswa. Hasil belajar mahasiswa digunakan sebagai acuan untuk menentukan keefektifan produk Modul, yaitu dengan menganalisis nilai pretest dan posttest.

\section{Hasil Belajar Kognitif Mahasiswa}

Hasil belajar kognitif mahasiswa yaitu berupa nilai hasil pretest dan posttes. Nilai pretest didapat dari hasil test sebelum mendapatkan pembelajaran menggunakan produk Modul dan nilai posttest didapat dari hasil test sesudah mendapatkan pembelajaran menggunakan produk Modul. Nilai hasil belajar pretest dan posttest disajikan pada tabel berikut.

Tabel 8 Hasil Pretest Mahasiswa

\begin{tabular}{ccc}
\hline Variabel & Data Pretest & Data Postest \\
\hline Jumlah mahasiswa & 40 & 40 \\
\hline Rata-rata & 67 & 82 \\
\hline Nilai terendah & 55 & 73 \\
\hline Nilai tertinggi & 78 & 93 \\
\hline
\end{tabular}

Dari tabel 8 menunjukkan bahwa rata-rata nilai untuk postest sudah yaitu 82 .

\section{Hasil Uji Normalitas}

Uji normalitas digunakan untuk mengetahui apakah data hasil belajar tersebut berdistribusi normal atau tidak. Asumsi bahwa populasi berdistribusi 
normal membantu menyelesaikan persoalan dengan mudah dan lancar. Uji normalitas data menggunakan program SPSS Statistics 16 dengan analisis Kolmogrov-Smirnov test. Hasil perhitungan uji normalitas data sebelum dan sesudah penggunaan Modul disajikan pada tabel berikut.

Tabel 9 Hasil Uji Normalitas Pretest dan Posttest Mahasiswa

\begin{tabular}{cccccc}
\hline Tindakan & $\begin{array}{c}\text { Banyak } \\
\text { Mahasiswa }\end{array}$ & Rata-rata & $\begin{array}{c}\text { Standar } \\
\text { Deviasi }\end{array}$ & Sig. & Interpretasi \\
\hline Pretest & 54 & 67 & 5,9 & 0,088 & Normal \\
\hline Posttest & 54 & 82 & 5,4 & 0,065 & Normal \\
\hline
\end{tabular}

Berdasarkan tabel 4.9 hasil uji normalitas nilai pretest dan posttest diperoleh signifikansi 0,088 (pretest) dan 0,065 (posttest). Kriteria pengujian pada normalitas data yaitu jika signifikansi > 0,05 maka $H_{0}$ diterima dan jika signifikansi $<0,05$ maka $H_{0}$ ditolak. Masing-masing nilai Sig. dari pretest dan posttest lebih dari 0,05 maka $H_{0}$ diterima. Jadi, data sebelum dan sesudah penggunaan Modul berdistribusi normal. Untuk hipotesis ujinya yaitu berikut ini.

$H_{0}$ : Distribusi populasi normal, jika probabilitas $>0,05, H_{0}$ diterima.

$H_{1}$ : Distribusi populasi tidak normal, jika probabilitas $\leq 0,05, H_{0}$ ditolak

\section{Hasil Uji Homogenitas}

Uji homogenitas digunakan untuk mengetahui data hasil pretest dan posttest homogen atau tidak. Uji homogenitas digunakan untuk menentukan rumus yang digunakan untuk menghitung uji peningkatan rata-rata. Kriteria pengujian homogenitas yaitu jika signifikansi $<0,05$ maka varian kelompok data tidak sama atau tidak homogenitas, dan jika signifikansi > 0,05 maka varian kelompok data adalah sama atau homogen. Uji homogenitas menggunakan SPSS

Statistics 16 dengan analisis Uji One Way ANOVA. Hasil perhitungan uji normalitas data sebelum dan sesudah penggunaan Modul disajikan pada tabel berikut. 
Tabel 10 Hasil Uji Homogenitas Pretest dan Posttest Mahasiswa

\begin{tabular}{cccc}
\hline $\begin{array}{c}\text { Levene } \\
\text { Statistic }\end{array}$ & df1 & df2 & Sig. \\
\hline $\begin{array}{c}\text { Pretest dan } \\
\text { posttest }\end{array}$ & 1 & 78 & 0,589 \\
\hline
\end{tabular}

Berdasarkan tabel 4.10 hasil uji homogenitas nilai pretest dan posttest di atas diperoleh signifikansi $>0,05$ yaitu 0,589 . Jadi dari hasil perhitungan tersebut dapat disimpulkan bahwa varian dari kedua kelompok data pretest dan posttest adalah homogen.

\section{Hasil uji t}

Penghitungan selanjutnya yaitu mencari perbedaan rata-rata nilai pretest dan posttest dengan melakukan uji t. Produk Modul dikatakan efektif dilihat dari perbedaan perbedaan rata-rata yang signifikan antara nilai pretest dan posttest. Untuk hipotesisnya yaitu sebagai berikut:

$H_{0}$ : tidak terdapat perbedaan yang signifikan hasil belajar mahasiswa antara sebelum dan sesudah dilakukan proses pembelajaran dengan menggunakan bahan ajar Modul

$H_{1}$ : terdapat perbedaan yang signifikan hasil belajar mahasiswa antara sebelum dan sesudah dilakukan proses pembelajaran dengan menggunakan bahan ajar Modul

Hasil perhitungan uji t data sebelum dan sesudah penggunaan Modul disajikan pada tabel berikut.

Tabel 11 Hasil Uji t Pretest dan Posttest Mahasiswa

\begin{tabular}{l|l|l}
\hline \multirow{2}{*}{ Kriteria } & Nilai & Posttest \\
\cline { 2 - 3 } & Pretest & 82 \\
\hline Mean & 67 & 5,38 \\
\hline Simpangan baku & 5,88 & 29,09 \\
\hline Varians & 35,31 & \\
\hline $\mathrm{R}$ & 0,49 & \\
\hline T hitung & 16,08 & \\
\hline Derajat Kebebasan & 39 & \\
\hline T tabel & 1,68 & \\
\hline
\end{tabular}


Harga $t_{\text {hitung }}>t_{\text {tabel }},(16,08>1,68)$ sehingga $H_{1}$ diterima. Jadi terdapat perbedaan yang signifikan hasil belajar mahasiswa antara sebelum dan sesudah dilakukan proses pembelajaran dengan menggunakan bahan ajar Modul

\section{Hasil Uji N-Gain}

Uji gain digunakan untuk mengetahui peningkatan rata-rata hasil belajar sebelum dan sesudah menggunakan Modul. Hasil uji peningkatan rata-rata data sebelum dan sesudah disajikan dalam tabel berikut.

Tabel 12. Hasil Uji-N Gain Pretest dan Posttest Mahasiswa

\begin{tabular}{ll}
\hline Kategori & Nilai \\
\hline Rata-rata Pretest & 67 \\
\hline Rata-rata posttest & 82 \\
\hline Selisih rata-rata & 15 \\
\hline Nilai gain & 0,45 \\
\hline Kriteria & Sedang \\
\hline
\end{tabular}

Berdasarkan tabel 12 hasil uji peningkatan rata-rata nilai (gain) pretest dan posttest mahasiswa sebesar 0,45 dan selisih rata-rata sebesar 15 . Hasil dari uji gain nilai pretest dan posttest mendapatkan kriteria sedang. Hasil peningkatan rata-rata nilai (gain) pretest dan posttest tersebut disajikan dalam diagram berikut.

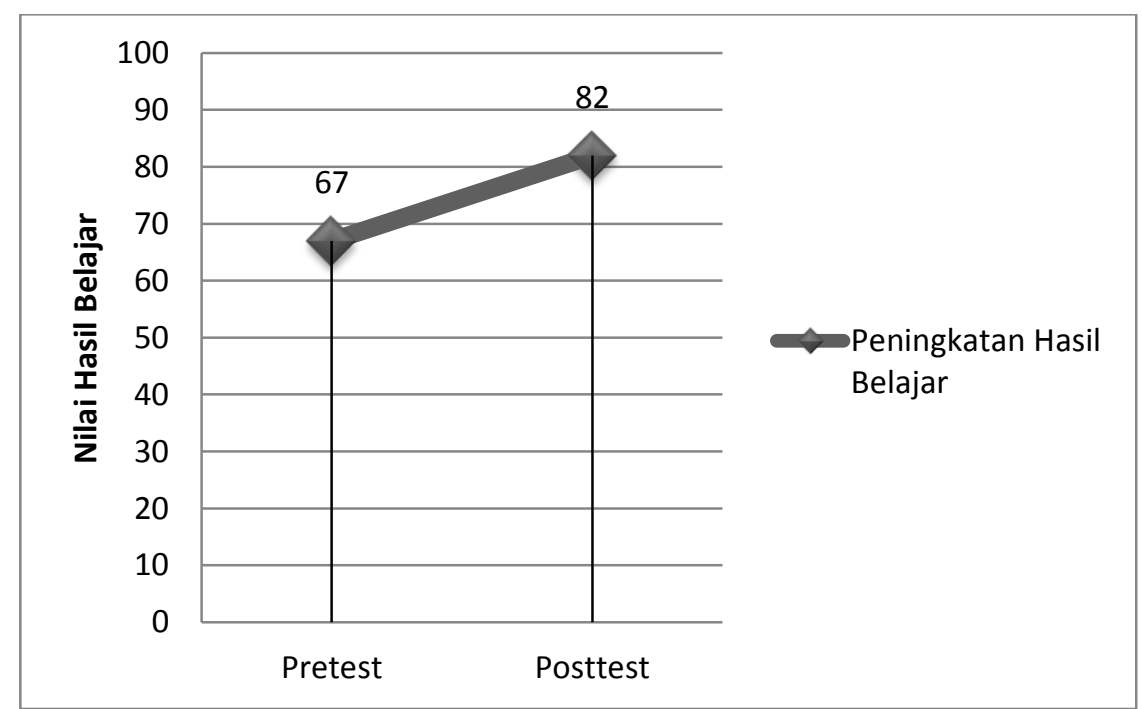

Gambar 3 Peningkatan Hasil Belajar Menggunakan Modul

Berdasarkan gambar 3 di atas menunjukkan bahwa adamya 
peningkatan rata-rata hasil belajar mahasiswa pada pretest dan posttest dengan selisih rata-rata sebesar 15 . Berdasarkan adanya peningkatan ratarata hasil belajar menunjukkan bahwa efektifnya penggunaan Modul Kimia Dasar.

\section{PEMBAHASAN}

\section{1) Kevalidan Modul Terintegrasi Socioscientific Issue (SSI) dan keIslaman}

Dalam penelitian ini, peneliti mengembangkan bahan ajar Modul kimia dasar pada materi molaritas dan laju reaksi. Pengukuran kevalidan bahan ajar didasarkan pada kelayakan isi, penyajian, kegrafikan, kebahasaan, ssi dan keislaman. Kevalidan bahan ajar didapatkan dari penilaian para ahli, baik ahli materi maupun ahli media. Proses penilaian dilakukan dengan mengisi instrumen validasi yang telah disediakan oleh peneliti.

Uji kelayakan dilakukan oleh 2 dosen sebagai ahli materi dan ahli media. Ahli materi menilai bahan ajar berdasarkan kelayakan isi, kelayakan penyajian, kelayakan kebahasaan dan kelayakan SSI dan keislaman. Dosen ahli media menilai bahan ajar berdasarkan kelayakan kegrafikan. Setiap aspek dalam penilaian kemudian diinterpretasikan dalam 4 kategori, yaitu skor 4 kategori sangat baik, skor 3 kategori baik, skor 2 kategori cukup, dan skor 1 kategori kurang. Kategori tersebut menggunakan skala likert menurut Sugiyono (2015:165169).

Validasi media pada ahli media dilakukan oleh dosen yang ahli di bidangnya yaitu Bapak Muhammad Isnaini, M.Pd (dosen Pendidikan Kimia FITK UIN Raden Fatah). Hasil penilaian oleh ahli media menunjukkan bahwa bahan ajar Modul sesuai dengan kriteria penilaian dalam aspek kelayakan kegrafikan. Ahli media pada validasi media memberikan skor 95\% dengan kriteria sangat layak. Validasi materi oleh ahli materi dilakukan oleh dosen yang ahli, Bapak Pandu Jati Laksono, M.Pd (dosen Prodi Pendidikan Kimia FITK UIN Raden Fatah) Hasil penilaian oleh ahli materi menunjukkan bahwa bahan ajar Modul sesuai kriteria penilaian meliputi kelayakan isi, kelayakan penyajian, kelayakan bahasa dan aspek penilaian SSI dan KeIslaman. Ahli materi pada validasi materi 
memberikan skor 95\% dengan kriteria sangat layak.

Kelayakan bahan ajar Modul tidak hanya dinilai dari kelayakan para pakar saja, namun juga masih harus melalui tahap uji coba skala kecil. Dalam uji coba skala kecil, pemakaian media tidak masuk dalam proses pembelajaran. Uji coba skala kecil dilakukan di luar jam pelajaran yakni dengan menggunakan kelas A Prodi Pendidikan Kimia sebanyak 9 mahasiswa. Pada tahap ini, semua mahasiswa yang terlibat dalam uji coba skala kecil dan dosen kelas diminta untuk mengisi angket tanggapan mahasiswa dan tanggapan dosen. Adapun hasil dari angket tanggapan mahasiswa tersebut yaitu diperoleh rata-rata skor sebesar 94\% dengan kategori sangat baik. Hasil dari angket tanggapan dosen diperoleh skor $80 \%$ dengan kriteria baik.

Berdasarkan penilaian dari ahli media, ahli materi, tanggapan mahasiswa dan dosen pada uji skala kecil menunjukkan bahwa bahan ajar Modul valid digunakan dalam proses pembelajaran.

\section{2) Keefektifan Penggunaan Modul Terintegrasi Socioscientific Issue (SSI) dan keIslaman}

Kefektifan penggunaan produk Modul dapat dilihat dari hasil belajar kognitif mahasiswa. Dalam penelitian ini, Pembelajaran dilakukan selama 4 pertemuan dikarenakan terbatasnya waktu dan dilakukan berdasarkan masukan dari dosen pengampu mata kuliah kimia dasar. Hasil belajar kognitif mahasiswa terdiri dari hasil nilai pretest dan posttest. Nilai pretest diperoleh dari hasil test sebelum pembelajaran menggunakan Modul, sedangkan nilai posttest diperoleh dari hasil test sesudah pembelajaran menggunakan Modul. Menurut Susanto (2016:5) memaknai hasil belajar adalah perubahan-perubahan yang terjadi pada diri mahasiswa, baik yang menyangkut aspek kognitif, afektif dan psikomotor sebagai hasil dari kegiatan belajar. Perubahan-perubahan yang terjadi pada diri mahasiswa menurut Susanto juga diharapkan berubah ke arah yang lebih baik. Nilai hasil belajar mahasiswa kelas A Prodi Pendidikan Kimia pada saat pretest dan posttest mengalami perbedaan. hasil pretest menunjukkan jumlah.

Peneliti menghitung nilai pretest dan posttest menggunakan uji t untuk 
mengetahui hasil belajar mahasiswa terjadi peningkatan yang signifikan atau tidak. Sebelum melakukan uji t, nilai pretest dan posttest diuji normalitas dan homogenitas terlebih dahulu. Dari hasil analisis data menunjukkan nilai pretest dan posttest memperoleh signifikansi 0,088 (pretest) dan 0,065 (posttest). Kriteria pengujian pada normalitas data yaitu jika signifikansi $>0,05$ maka $H_{0}$ diterima dan jika signifikansi $<0,05$ maka $H_{0}$ ditolak. Dengan demikian nilai pretest dan posttest berdistribusi normal.

Selanjutnya adalah uji homogenitas untuk mengetahui data nilai pretest dan posttest merupakan varians yang sama (homogen) atau tidak.. Hasil uji homogenitas nilai pretest dan posttest di atas diperoleh signifikansi > 0,05 yaitu 0,589. Jadi dari hasil perhitungan tersebut dapat disimpulkan bahwa varian dari kedua kelompok data pretest dan posttest adalah homogen.

Setelah diketahui data normal dan homogen, maka dapat dihitung signifikan atau tidak kenaikan hasil belajar tersebut menggunakan uji $t$. Uji $t$ yang digunakan untuk sampel berkorelasi dengan dua hipotesis statistik yaitu $H_{0}$ dan $H_{1} . H_{0}$ berbunyi tidak terdapat perbedaan yang signifikan hasil belajar mahasiswa antara sebelum dan sesudah dilakukan proses pembelajaran dengan menggunakan bahan ajar Modul. sedangkan $H_{1}$ berbunyi terdapat perbedaan yang signifikan hasil belajar mahasiswa antara sebelum dan sesudah dilakukan proses pembelajaran dengan menggunakan bahan ajar Modul.

Uji $t$ yang digunakan untuk sampel yang saling berhubungan, karena menguji pretest dan posttest dengan satu sampel yang sama. Dari hasil uji $t$ didapatkan simpulan bahwa diperoleh harga $t_{\text {hitung }}>t_{\text {tabel }}(16,08>1,68)$ sehingga $\mathrm{H}_{1}$ diterima. Jadi terdapat perbedaan yang signifikan hasil belajar mahasiswa antara sebelum dan sesudah dilakukan proses pembelajaran dengan menggunakan bahan ajar Modul

Uji t tersebut didukung dengan uji n gain pretest dan posttest. Hasil uji peningkatan rata-rata nilai (gain) pretest dan posttest mahasiswa kelas A Prodi Pendidikan Kimia sebesar 0,45 dan selisih rata-rata sebesar 15. Hasil dari uji n gain nilai pretest dan posttest mendapatkan kriteria sedang.

Berdasarkan pemaparan tersebut, dapat disimpulkan bahwa hasil belajar 
mahasiswa dari sebelum dan setelah menggunakan Modul ini mengalami peningkatan "sedang” dan"signifikan", sehingga dinyataka efektif.

\section{3) Respon Mahasiswa}

Respon mahasiswa terhadap modul yang dikembangkan dapat dilihat dari uji coba skala kecil dan uji coba skala besar. Uji coba skala kecil menunjukkan bahwa respon bagi modul adalah sangat baik Hal tersebut ditunjukkan dengan hasil persentase paling rendah hanya 83\% untuk aspek 6 yaitu Modul ini terdapat beberapa bagian untuk saya menemukan konsep sendiri. Sedangkan persentase paling tinggi yaitu $100 \%$ untuk aspek 1, 8, dan 10. Sedangkan respons mahasiswa secara klasikal diperoleh skor 94\% dengan kriteria sangat baik. Pada uji coba skala besar respon mahasiswa menunjukkan tanggapan yang sangat baik bagi produk Modul yang diuji cobakan. Hal tersebut ditunjukkan dengan hasil persentase paling rendah hanya $81 \%$ untuk aspek 2 dan 7 yaitu Modul ini membuat saya lebih bersemangat belajar dan penyajian materi dalam Modul ini mendorong saya untuk berdiskusi dengan teman yang lain. Sedangkan persentase paling tinggi yaitu $89 \%$ untuk aspek 1 yaitu tampilan Modul ini menarik. Sedangkan respons mahasiswa secara klasikal diperoleh skor $85 \%$ dengan kriteria sangat baik.

\section{KESIMPULAN}

Berdasarkan hasil penelitian dapat disimpulkan beberapa hal sebagai berikut:

1. Telah dihasilkan Modul yang terintegrasi socio-sicnetific issue (SSI) dan ke Islaman yang memenuhi kriteria valid dari penilaian para ahli pada aspek kelayakan isi, kelayakan penyajian, kegrafikan, kebahasaan, dan integrrasi ssi dan keislaman.

2. Telah dihasilkan Modul yang terintegrasi socio-scientific issue (SSI) dan ke Islaman yang efektif digunakan untuk meningkatkan hasil belajar kimia dasar pada materi molaritas dan laju reaksi ditinjau dari peningkatan hasil belajar mahasiswa dalam ranah kognitif dengan menggunakan analisis nilai pretest dan posttest. Hasil analisis uji-t diperoleh harga $t_{\text {hitung }} 16,08$ dan hasil analisis $\mathrm{N}$-gain menunjukkan bahwa nilai $\mathrm{N}$-gain diperoleh sebesar 0,45 . Hal 
ini berarti bahwa telah terjadi peningkatan secara signifikan dengan kategori sedang.

3. Produk Modul yang terintegrasi socio-scientific issue (SSI) dan ke Islaman yang telah dikembangkan mendapatkan respon yang baik dari mahasiswa dengan nilai persentase lebih dari $85 \%$

\section{DAFTAR RUJUKAN}

Fowler, S. R., Zeidler, D. L., \& Sadler, T. D. (2009). Moral Sensitivity in the Context of Socioscientific Issues in High School Science Students. International Journal of Science Education, 31(January 2015), 279-296. http://doi.org/10.1080/09500690701787909

Lee hlee25@ewha.ac.kr, H., Yoo, J., Choi, K., Kim, S.-W., Krajcik, J., Herman, B. C. ., \& Zeidler, D. L. . (2013). Socioscientific Issues as a Vehicle for Promoting Character and Values for Global Citizens. International Journal of Science Education, 35(January 2015), 2079-2113. http://doi.org/10.1080/09500693.2012.749546

Coletta,V.P., Phillips, J.A. 2005. Interpreting FCI scores: Normalized gain, preinstruction scores, and scientific reasoning ability. American Journal Physic. 73 12, December 2005

Coe, Robert. 2002. It's the Effect Size, Stupid 1 What effect size is and why it is important. (Online). (http://www.cem.org/attachments/ebe/ESguide.pdf), diakses tanggal 25 Mei 2015

Thiagarajan, Sivasailes. 1974. Instructional Development for Training Teachers of Exceptional Children. Minneapolis, Minnesota: Leadership Training Institute/Special Education, University of Minnesota

Sadler,T.D \& Zeidler, D.L. 2004. The morality of socioscientific issues: Construal and resolution of genetic engineering dilemmas. Science Education, 88 (1), 4-27

Morris, H. (2014). International Journal of Science Socioscientific Issues and Multidisciplinarity in School Science Textbooks, (January 2015), 37-41. http://doi.org/10.1080/09500693.2013.848493

Cheng, M., Chou, P., Wang, Y., \& Lin, C. (2015). Learning effects of a science textbook designed with adapted cognitive process principles on grade 5 students, (October 2013), 467-488.

Fibonacci, A. (2014). Development Fun-Chem Learning Materials Integrated Socio-Science Issues to Increase Students Scientific Literacy, 3(11), 708- 
713.

Darda, Abu. 2015. Integrasi Ilmu dan Agama: Perkembangan Konseptual di Indonesia. Jurnal At-Ta'dib. Vol. 10. No. 1, Juni 2015

Purwanto, N. 2013. Evaluasi Hasil Belajar. Yogyakarta: Pustaka Pelajar 